\title{
AKTYWNOŚĆ PLANISTYCZNA ADMINISTRACJI PUBLICZNEJ W SFERZE OCHRONY RODZINY I OPIEKI NAD NIĄ
}

\begin{abstract}
Streszczenie. Celem studium jest ukazanie planistycznej aktywności administracji publicznej w sferze ochrony rodziny i opieki nad nią. Aktywność tę kształtują zadania nakładane przez prawodawcę na podmioty administracji publicznej. W opracowaniu położono nacisk na wyeksponowanie zarówno szerokiego wachlarza zaangażowanych podmiotów, jak i różnorodności form aktów planowania. Zwrócono także uwagę na charakter prawny aktów planowania.
\end{abstract}

Slowa kluczowe: rodzina, opieka i ochrona, administracja publiczna, planowanie, zadania publiczne.

\section{ZAGADNIENIA WPROWADZAJĄCE}

Chociaż planowanie jest jednym z podstawowych terminów ekonomii i teorii organizacji, bez wątpienia należy stwierdzić, iż jest to też pojęcie prawne i prawnicze. Zastosowanie szerokiego wachlarza tego rodzaju form aktywności administracji świadczy o roli, jaką prawodawca wyznacza planowaniu. Wystarczy przywołać kluczową definicję zawartą w jednym z głównych aktów prawnych regulujących tę materię - w ustawie o wspieraniu rodziny i systemie pieczy zastępczej ${ }^{1}$, gdzie przez wspieranie rodziny rozumie się zespół planowych działań mających na celu przywrócenie rodzinie przeżywającej trudności w wypełnianiu funkcji opiekuńczo-wychowawczej zdolności do wypełniania tej funkcji.

Słusznie podkreśla J. H. Szlachetko, że

planowanie jest reakcją na przyszłość, próbą jej zdeterminowania, a przynajmniej chęcią asekuracji przed zjawiskami negatywnymi. Immanentną cechą planowania jest rozciągnięcie w czasie. W zasadzie można by się pokusić o konstatację, że proces ten powinien być prowadzony bez końca, gdyż dotyczy przedziału czasowego zamkniętego ${ }^{2}$.

* Łódzki Urząd Wojewódzki w Łodzi.

1 T.j. Dz. U. 2015, poz. 332, dalej: uwr.

2 J. H. Szlachetko, Uwagi na temat wspótpracy podmiotów spoza systemu administracji publicznej przy stanowieniu aktów planistycznych przez organy administracji zdecentralizowanej, [w:] M. Stec, M. Mączyński (red.) Partycypacja obywateli i podmiotów obywatelskich w podejmowaniu rozstrzygnięć publicznych na poziomie lokalnym, LEX 2012, nr 154449. 
Należy powtórzyć za T. Kotarbińskim, iż planowanie jest ,obmyślaniem (projektowaniem) koncepcji działań przyszłych"3. Planowanie jest istotną właściwością działań służących opiece nad rodziną i jej ochronie. Rodzimy ustawodawca przyjął szereg aktów prawnych, skoncentrowanych na rodzinie. W szczególności należy tu wymienić: ustawę z dnia 12 marca 2004 r. o pomocy społecznej ${ }^{4}$, ustawę z dnia 29 lipca 2005 r. o przeciwdziałaniu przemocy w rodzinie ${ }^{5}$, przywołaną już ustawę z dnia 9 czerwca 2011 r. o wspieraniu rodziny i systemie pieczy zastępczej, ustawę z dnia 28 listopada 2003 r. o świadczeniach rodzinnych ${ }^{6}$, ustawę z dnia 4 lutego 2011 r. o opiece nad dziećmi w wieku do lat $3^{7}$, ustawę z dnia 5 grudnia 2014 r. o Karcie Dużej Rodziny ${ }^{8}$. Niemalże wszystkie spośród wymienionych ustaw przewidują obowiązek bądź zakładają ewentualność tworzenia aktów planowania. Wiele aktów prawnych, których przedmiot regulacji nie dotyczy rodziny bezpośrednio, również zawiera podstawę planistycznej aktywności administracji w zakresie ochrony rodziny i opieki nad nią .

Celem niniejszego opracowania jest ukazanie, że planowanie, którego głównym przejawem jest stanowienie różnego typu planów, programów, strategii stanowi istotny fragment aktywności administracji publicznej w sferze ochrony rodziny i opieki nad nią. U jej podstaw leżą zadania nakładane przez prawodawcę na podmioty administracji publicznej.

\section{ZADANIA PODMIOTÓW ADMINISTRACJI PUBLICZNEJ ZWIĄZANE Z PLANOWANIEM}

Działalność planistyczna administracji w zakresie ochrony rodziny i opieki nad nią jest w dużej mierze konsekwencją zadań nakładanych przepisami prawa, rozproszonych w wielu aktach prawnych, na podmioty usytuowane na różnych poziomach struktury administracji publicznej. Niejednokrotnie realizacja danego zadania związana jest z koniecznością udziału dwóch lub większej liczby podmiotów (np. zgodnie z art. 62 ust. 1 ustawy o opiece nad dziećmi w wieku do lat 3 wojewoda współpracuje z ministrem przy opracowaniu i realizacji resortowych oraz rządowych programów rozwoju instytucji opieki nad dziećmi w wieku do

3 T. Kotarbiński, Walory dobrego planu, ,Nauka Polska” 1960, nr 1.

${ }^{4}$ T.j. Dz. U. 2015, poz. 163 ze zm., dalej: ups.

${ }^{5}$ Dz. U. 2005, nr 180, poz. 1493 ze zm., dalej: ppr.

${ }^{6}$ T.j. Dz. U. 2015, poz. 114.

7 T.j. Dz. U. 2013, poz. 1457, dalej: ond.

${ }^{8}$ Dz. U. 2014, poz. 1863, dalej: kdr.

9 Są to np.: ustawa z dnia 26 października 1982 r. o wychowaniu w trzeźwości i przeciwdziałaniu alkoholizmowi (t.j. Dz. U. 2012, poz. 1356 ze zm.) czy ustawa z dnia 27 sierpnia 2009 r. o finansach publicznych (t.j. Dz. U. 2013, poz. 885 ze zm.). 
lat 3). Zasadniczy trzon omawianych zadań stanowią te polegające na planowaniu sensu stricto. Zaznaczyć należy, iż konstruując przepisy wyznaczające zadania w zakresie planowania, prawodawca posługuje się niejednolitymi określeniami - do najczęściej spotykanych należą „tworzy”, „opracowuje”, „przyjmuje”, „wprowadza”.

Przed dokonaniem wyliczenia zadań planistycznych sensu stricto, należy poczynić uwagę, iż nie wyczerpują one katalogu zadań związanych z planowaniem. Przepisy prawa nakładają na organy administracji publicznej szereg powiązanych obowiązków. Istotną część stanowią zadania związane z finansowaniem ${ }^{10}$ planów, programów czy strategii: np. zgodnie z art. 23 ust. 1 pkt 7a ups minister właściwy do spraw zabezpieczenia społecznego wspiera finansowo programy w określonym przez siebie obszarze pomocy społecznej, realizowane przez jednostki samorządu terytorialnego lub podmioty uprawnione; art. 187 ust. 1 pkt 2 uwr stanowi z kolei, iż minister do spraw rodziny udziela finansowego wsparcia gminnym programom wspierania rodziny i powiatowym programom dotyczących rozwoju systemu pieczy zastępczej. Na mocy art. 23 ust. 1 pkt 7 ups na ministra właściwego do spraw zabezpieczenia społecznego nałożony został obowiązek finansowania programów osłonowych w obszarze pomocy społecznej.

Kolejną grupę stanowią zadania polegające na powoływaniu podmiotów odpowiedzialnych za realizację planów, programów i strategii, np. wojewoda powołuje i odwołuje Wojewódzkiego Koordynatora Realizacji Krajowego Programu Przeciwdziałania Przemocy w Rodzinie (art. 7 ust. 1 pkt 3 ppr) i określaniu wymogów, które takie podmioty muszą spełniać (np. zgodnie z art. 7 ust. 3 pkt 2 ppr minister właściwy do spraw zabezpieczenia społecznego określa w drodze rozporządzenia kwalifikacje Wojewódzkiego Koordynatora Krajowego Programu Przeciwdziałania Przemocy w Rodzinie, uwzględniając konieczność zapewnienia odpowiedniego poziomu wykonywania zadań).

10 Środki na realizację większości analizowanych programów i strategii pochodzą z budżetu państwa. Zwykle ustawodawca, statuując dany akt planowania, określa źródła jego finansowania. Należy zaznaczyć, iż przywołane unormowania różni stopień szczegółowości regulowania kwestii finansowych. Wprowadzenie ogólnokrajowych regulacji częstokroć nie zamyka jednostkom samorządu terytorialnego możliwości przyznania dodatkowych uprawnień danej grupie beneficjentów, jednakże ciężar finansowania przenoszony jest na gminę, powiat czy województwo samorządowe. Taka sytuacja ma miejsce np. w przypadku regulacji dotyczących wsparcia dla rodzin wielodzietnych. W dniu 5 grudnia 2014 r. została uchwalona ustawa o Karcie Dużej Rodziny. Wskazany akt prawny zastąpił rządowy program dla rodzin wielodzietnych, przyjęty przez Radę Ministrów uchwałą nr 85 z dnia 27 maja 2014 r. Ustawodawca wskazał, iż przyznawanie Karty jest zadaniem z zakresu administracji rządowej i jego realizacja finansowana jest $\mathrm{z}$ budżetu państwa (art. 29 ust. 1 i 2). Na mocy art. 27 ust. 1 ustawy, rada gminy, rada powiatu oraz sejmik województwa mogą uchwalać jednak samorządowe programy przyznające uprawnienia członkom rodzin wielodzietnych. Przyjmowanie i realizacja takich programów jest zadaniem własnym samorządu terytorialnego. Jak wynika wprost z art. 29 ust. 11 ustawy o Karcie Dużej Rodziny, samorządowy program przyznający uprawnienia członkom rodzin wielodzietnych nie jest finansowany ze środków budżetu państwa. 
Uwagę należy zwrócić także na zadania o charakterze nadzorczo-kontrolnym (jako przykład wskazać można unormowania art. 23 ust. $1 \mathrm{~b}$ ups, zgodnie z którym minister właściwy do spraw zabezpieczenia społecznego może dokonywać kontroli i oceny realizacji programów, które wspiera finansowo; $\mathrm{z}$ kolei zgodnie $\mathrm{z}$ art. 7 ust. 1 pkt 4 ppr wojewoda przy pomocy Wojewódzkiego Koordynatora Realizacji Krajowego Programu Przeciwdziałania Przemocy w Rodzinie monitoruje realizację Krajowego Programu Przeciwdziałania Przemocy w Rodzinie) czy sprawozdawczości (zgodnie z art. 11 ppr Rada Ministrów składa corocznie Sejmowi i Senatowi Rzeczypospolitej Polskiej, w terminie do dnia 30 września, sprawozdanie z realizacji Krajowego Programu Przeciwdziałania Przemocy w Rodzinie).

Zadania o charakterze planistycznym służące ochronie rodziny i opiece nad nią na poziomie administracji rządowej zostały przypisane Radzie Ministrów, ministrowi - w głównej mierze ministrowi kierującemu działami sprawy rodziny oraz zabezpieczenie społeczne (zgodnie z $§ 1$ pkt 2 rozporządzenia Prezesa Rady Ministrów z dnia 22 września 2014 r. w sprawie szczegółowego zakresu działania Ministra Pracy i Polityki Społecznej ${ }^{11}$ działami tymi kieruje Minister Pracy i Polityki Społecznej) oraz wojewodzie. Przepisy stanowiące podstawę tworzenia aktów planowania służących mogą zawierać nakaz przyjęcia danego aktu planowania; ich opracowanie może być też przejawem dyskrecjonalnej władzy administracji $1^{12}$.

Obowiązkiem Rady Ministrów jest przyjęcie Krajowego Programu Przeciwdziałania Przemocy w Rodzinie ${ }^{13}$ oraz zatwierdzanie Narodowego Programu Przeciwdziałania Alkoholizmowi ${ }^{14}$. Z kolei przepisy ustawy o pomocy społecznej dają temu organowi możliwość przyjęcia rządowego programu mającego na celu ochronę poziomu życia osób, rodzin i grup społecznych oraz rozwój specjalistycznego wsparcia. Jak wynika z art. 187a ust. 1 uwr, fakultatywny charakter ma także przyjęcie rządowego programu wsparcia rodzin z dziećmi.

W świetle obecnie obowiązujących unormowań prawnych Minister Pracy i Polityki Społecznej: tworzy koncepcje i określa kierunki rozwoju w obszarze pomocy społecznej (art. 23 ust. 1 pkt 1 ups), opracowuje programy osłonowe w obszarze pomocy społecznej (art. 23 ust. 1 pkt 7 ups), opracowuje resortowe oraz rządowe programy rozwoju instytucji opieki nad dziećmi w wieku do lat 3 oraz finansowo wspiera te programy (art. 62 ust. 1 ond), opracowuje rządowe programy wspierania rodziny i systemu pieczy zastępczej (art. 187 ust. 1 pkt 5 uwr).

${ }^{11}$ Dz. U. 2014, poz. 1260.

${ }_{12}$ Zob. Z. Duniewska, [w:] M. Stahl (red.), Materialne prawo administracyjne. Pojęcia, instytucje, zasady w teorii i orzecznictwie, Wolters Kluwer SA, Warszawa 2009, s. 90; M. Jaśkowska, Uznanie administracyjne a inne formy władzy dyskrecjonalnej administracji publicznej, [w:] R. Hauser, Z. Niewiadomski, A. Wróbel (red.), System prawa administracyjnego. Instytucje prawa administracyjnego, Warszawa 2010, s. 213-303.

${ }_{13}$ Art. 10 ust. 1 ppr.

${ }^{14}$ Art. 2 ust. 2 ustawy o przeciwdziałaniu alkoholizmowi. 
Do zadań ministra należy ponadto opracowanie programów osłonowych z zakresu przeciwdziałania przemocy w rodzinie (art. 8 pkt 6 ppr). Ponadto został na niego nałożony obowiązek wprowadzenia programu na dofinansowanie, w okresie 6 lat od dnia wejścia w życie ustawy o wspieraniu rodziny i systemie pieczy zastępczej, zadań własnych gminy i powiatu z zakresu realizacji zadań wspierania rodziny oraz systemu pieczy zastępczej, w szczególności na pokrycie części wydatków związanych z powołaniem asystentów rodziny, koordynatorów rodzinnej pieczy zastępczej oraz prowadzeniem szkoleń dla rodzin zastępczych i prowadzących rodzinne domy dziecka (art. 247 ust. 1 uwr). Zadanie to minister realizuje we współpracy z wojewodą (art. 247 ust. 1a uwr). Podobna sytuacja ma miejsce przy opracowaniu resortowych oraz rządowych programów rozwoju instytucji opieki nad dziećmi w wieku do lat 3 (art. 62 ust. 1 ond).

Wojewoda współdziała z ministrem przy opracowywaniu programów wspierania rodziny i systemu pieczy zastępczej (186 pkt 7 uwr). Planowanie służące ochronie rodziny i opiece nad nią jest też zadaniem jednostek samorządu terytorialnego wszystkich szczebli. Warto zwrócić uwagę na dwojaki sposób konstruowania przepisów: w większości przypadków zadania nakładane są na gminę, powiat czy województwo samorządowe, zdarza się jednak, iż prawodawca wyznacza zadanie konkretnemu organowi samorządu terytorialnego. Nie bez znaczenia jest też tradycyjny podział zadań jednostek samorządu terytorialnego na własne i zlecone ${ }^{15}$.

Województwo samorządowe, jako zadanie własne: opracowuje, aktualizuje i realizuje strategię wojewódzką w zakresie polityki społecznej będącą integralną częścią strategii rozwoju województwa obejmującą w szczególności programy: przeciwdziałania wykluczeniu społecznemu, wyrównywania szans osób niepełnosprawnych, pomocy społecznej, profilaktyki i rozwiązywania problemów alkoholowych, współpracy z organizacjami pozarządowymi - po konsultacji z powiatami (art. 21 pkt 1 ups); rozpoznaje przyczyny ubóstwa oraz opracowuje regionalne programy pomocy społecznej wspierające samorządy lokalne w działaniach na rzecz ograniczania tego zjawiska (art. 21 pkt 3 ups); opracowuje programy dotyczące wspierania rodziny i systemu pieczy zastępczej, będące integralną częścią strategii rozwoju województwa (art. 183 pkt 2 uwr). Ponadto, zgodnie z art. 27 ust. $2 \mathrm{kdr}$, sejmik województwa może uchwalić samorządowy program przyznający uprawnienia członkom rodzin wielodzietnych.

Do kategorii zadań zleconych samorządowi województwa należy realizacja zadań wynikających z rządowego programu wsparcia rodzin z dziećmi (art. 184 uwr), opracowanie i realizacja wojewódzkiego programu przeciwdziałania przemocy w rodzinie (art. 6 ust. 6 pkt 1 ppr), opracowanie ramowych programów

15 Szerzej na temat zadań samorządu terytorialnego: Z. Niewiadomski, Samorząd terytorialny, [w:] R. Hauser, Z. Niewiadomski, T. Wróbel (red.), System prawa administracyjnego, t. 6: Podmioty administrujące, C.H. Beck, Warszawa 2011, s. 129-161. 
ochrony ofiar przemocy w rodzinie oraz ramowe programy oddziaływań korekcyjno-edukacyjnych dla osób stosujących przemoc w rodzinie (art. 6 ust. 6 pkt 3 ppr).

Powiat $\mathrm{w}$ ramach zadań własnych opracowuje i realizuje powiatową strategię rozwiązywania problemów społecznych, ze szczególnym uwzględnieniem programów pomocy społecznej, wspierania osób niepełnosprawnych i innych, których celem jest integracja osób i rodzin z grup szczególnego ryzyka - po konsultacji z właściwymi terytorialnie gminami; podejmuje inne działania wynikające $\mathrm{z}$ rozeznanych potrzeb, w tym tworzy i realizuje programy osłonowe (art. 19 pkt 16 ups), opracowuje i realizuje 3-letnie powiatowe programy dotyczące rozwoju pieczy zastępczej, zawierające między innymi coroczny limit rodzin zastępczych zawodowych (art. 180 pkt 1 uwr), opracowuje i realizuje powiatowy program przeciwdziałania przemocy w rodzinie oraz ochrony ofiar przemocy w rodzinie (art. 6 ust. 3 pkt 1 ppr), opracowuje i realizuje programy służące działaniom profilaktycznym mającym na celu udzielenie specjalistycznej pomocy, zwłaszcza w zakresie promowania i wdrożenia prawidłowych metod wychowawczych w stosunku do dzieci w rodzinach zagrożonych przemocą w rodzinie (art. 6 ust. 3 pkt 2 ppr). Zadania planistyczne zostały także przypisane radzie powiatu, która na podstawie art. 112 ust. 13 ups opracowuje i wdraża lokalne programy pomocy społecznej. Ponadto rada powiatu może uchwalić samorządowy program przyznający uprawnienia członkom rodzin wielodzietnych (art. 27 ust. $2 \mathrm{kdr}$ ).

Zadaniem z zakresu administracji rządowej realizowanym przez powiat jest opracowywanie i realizacja programów oddziaływań korekcyjno-edukacyjnych dla osób stosujących przemoc w rodzinie (art. 6 ust. 4 pkt 2 ppr). Do tej grupy należy także realizacja zadań wynikających z rządowych programów pomocy społecznej, mających na celu ochronę poziomu życia osób, rodzin i grup społecznych oraz rozwój specjalistycznego wsparcia (art. 20 ust. 1 pkt 3 ups) oraz realizacja zadań wynikających z rządowych programów wspierania rodziny i systemu pieczy zastępczej oraz rządowego programu wsparcia rodzin z dziećmi (art. 181 pkt 1 uwr).

Gmina, jako zadanie własne:

1) opracowuje i realizuje gminną strategię rozwiązywania problemów społecznych ze szczególnym uwzględnieniem programów pomocy społecznej, profilaktyki i rozwiązywania problemów alkoholowych i innych, których celem jest integracja osób i rodzin z grup szczególnego ryzyka (art. 17 ust. 1 pkt 1 ups);

2) opracowuje i realizuje 3-letnie gminne programy wspierania rodziny (art. 176 pkt 1 uwr);

3) opracowuje i realizuje gminny program przeciwdziałania przemocy w rodzinie oraz ochrony ofiar przemocy w rodzinie (art. 6 ust. 2 pkt 1 ppr);

4) tworzy i realizuje programy osłonowe wynikające $z$ rozeznanych potrzeb gminy z zakresu pomocy społecznej (art. 17 ust. 2 pkt 4 ups).

Rada gminy, biorąc pod uwagę potrzeby związane z realizacją zadań wspierania rodziny, uchwala gminne programy wspierania rodziny (art. 179 ust. 2 uwr), 
natomiast biorąc pod uwagę potrzeby w zakresie pomocy społecznej, opracowuje i kieruje do wdrożenia lokalne programy pomocy społecznej (art. 110 ust. 10 ups). Może też uchwalić samorządowy program przyznający uprawnienia członkom rodzin wielodzietnych (art. 27 ust. $1 \mathrm{kdr}$ ).

Jako zlecone, gmina wykonuje zadania wynikające $\mathrm{z}$ rządowych programów z zakresu wspierania rodziny oraz rządowego programu wspierania rodziny z dziećmi (art. 177 ust. 1 uwr). Do grupy tej należą także zadania wynikające z rządowych programów pomocy społecznej, mających na celu ochronę poziomu życia osób, rodzin i grup społecznych oraz rozwój specjalistycznego wsparcia (art. 18 ust. 1 pkt 6 ups).

\section{POJĘCIE I CHARAKTERYSTYKA AKTÓW PLANOWANIA SŁUŻĄCYCH OCHRONIE RODZINY I OPIECE NAD NIĄ}

Określenie akty planowania - w szerokim rozumieniu - nawiązując do definicji przyjętej przez D. Dąbek ${ }^{16}$, będę odnosiła do aktów o planowym bądź programowym charakterze, tworzonych przez podmioty administracji publicznej i służących ochronie rodziny i opiece nad nią.

Akty planowania stanowią zróżnicowaną kategorię - mają niejednolity charakter i opracowywane są przez rozliczne podmioty. Aktom tym nadawane są różne nazwy. Wskazać można na istnienie m.in.: planów, strategii, programów, priorytetów, warunków, koncepcji, perspektyw, studiów, koncepcji, założeń, studiów, raportów, rezolucji, odezw ${ }^{17}$.

W doktrynie przyjmuje się, że, ,występowanie wielu z tych form umotywowane jest w dużej mierze rangą przypisywaną menedżerskiej funkcji administracji, w tym potrzebie podejmowania bardziej racjonalnych, spójnych decyzji o charakterze strategicznym"18. Jak zauważają Z. Duniewska, M. Górski, B. Jaworska-Dębska, E. Olejniczak-Szałowska, M. Stahl, formy te determinowane są przede wszystkim normami zadaniowymi i wynikającymi z nich obowiązkami. Z założenia mają one sprzyjać koordynacji działań, współdziałaniu, wspieraniu i aktywizacji rozmaitych podmiotów. Przy korzystaniu z tych form większą uwagę zwraca się na tak eksponowaną ostatnio rolę partnerstwa (gospodarczego i społecznego),

16 D. Dąbek, Prawo miejscowe, Wolters Kluwer SA, Warszawa 2015, s. 151.

${ }^{17}$ Szerzej zob. ibidem, s. 152; M. Stahl, Szczególne prawne formy dziatania administracji, [w:] R. Hauser, Z. Niewiadomski, A. Wróbel (red.), System prawa administracyjnego, t. 6, s. 370.

${ }^{18}$ Z. Duniewska, M. Górski, B. Jaworska-Dębska, E. Olejniczak-Szałowska, M. Stahl, Plany, strategie, programy i inne zbliżone formy prawne działania administracji publicznej, [w:] Podmioty administracji publicznej i prawne formy ich działania. Studia i materiały z Konferencji Naukowej poświęconej Jubileuszowi 80-tych urodzin Profesora Eugeniusza Ochendowskiego, Towarzystwo Naukowe Organizacji i Kierownictwa „Dom Organizatora”, Toruń, 15-16 listopada 2005, s. 143. 
będącego jednym z przejawów demokratyzacji, także w sferze podejmowanych przez administrację działań ${ }^{19}$.

Zdaniem M. Górskiego i J. Kierzkowskiej akty planowania są „aktami polityki administracyjnej, rozumianej jako polityka wykonywania przez administrację publiczną w różnych dziedzinach różnych zadań publicznych, ustalania celów i priorytetów, projektowania środków i sposobów działania oraz przewidywania efektów"20.

Nie ma jednolitego stanowiska przedstawicieli nauki prawa administracyjnego co do charakteru form aktywności administracji określanych wyżej wskazanymi nazwami. D. Dąbek zwraca uwagę na dwa typy przypadków. Jak wskazuje,

może być tak, że dany akt stanowiący rezolucję, odezwę czy plan, pozbawiony będzie cech normatywności, stanowiąc jedynie wyraz ocen i życzeń, ale może też być tak, że zawierał będzie normy prawne, tyle że o specyficznym charakterze. Jeżeli zatem dany akt będzie określał jedynie zadania do wykonania (cel, jaki ma być osiągnięty), a nie nakazane lub zakazane działania, nie będzie miał charakteru normatywnego. Jeżeli natomiast wskazany zostanie, choćby nawet w sposób bardzo ogólny, sposób zrealizowania tego zadania i podmiot zobowiązany do wykonania tego zadania, będzie jednak miał charakter aktu normatywnego, tyle, że specyficznego - tzw. aktu planowania $^{21}$.

Ustrojodawca w art. 87 ust. 2 Konstytucji RP nie wyodrębnił wśród źródeł prawa aktów planowania. Można zatem przyjąć, iż co do zasady nie mają one charakteru aktów normatywnych. Inna sytuacja ma miejsce, gdy ustawa wprost nada im taki charakter.

Na szczeblu administracji rządowej (centralnej) kompetencje w zakresie stanowienia aktów planowania dotyczących rozważanej problematyki posiada Rada Ministrów i ministrowie kierujący wskazanymi przepisami ustawowymi działami administracji rządowej. Ich aktywność planistyczna przejawia się najczęściej w stanowieniu programów przybierających z reguły formę uchwały bądź rozporządzenia.

Zgodnie z unormowaniami konstytucyjnymi zarówno minister resortowy, jak i Rada Ministrów posiadają kompetencję wydawania rozporządzeń (art. 148 pkt 3 oraz art. 149 ust. 2 zd. 1 Konstytucji RP). Jak wynika $z$ art. 87 ust. 1 ustawy zasadniczej, rozporządzenia są źródłem powszechnie obowiązującego prawa Rzeczypospolitej Polskiej. Wydawane są na podstawie szczegółowego upoważnienia zawartego $\mathrm{w}$ ustawie i w celu jej wykonania. Upoważnienie powinno określać (oprócz organu właściwego do wydania rozporządzenia) zakres spraw przekazanych do uregulowania oraz wytyczne dotyczące treści aktu. Akty planowania

19 Ibidem.

${ }^{20}$ M. Górski, J. Kierzkowska, Strategie, plany i programy, [w:] R. Hausner, Z. Niewiadomski, A. Wróbel (red.), System prawa administracyjnego, t. 7: Prawo administracyjne materialne, C.H. Beck, Warszawa 2012, s. 189-190.

${ }^{21}$ D. Dąbek, op. cit., s. 152. 
stanowione przez Radę Ministrów częstokroć przybierają też postać jej uchwały bądź załącznika do uchwały. Jak wynika z art. 93 ust. 1 Konstytucji RP, uchwały Rady Ministrów mają charakter wewnętrzny i obowiązują tylko jednostki organizacyjne podległe organowi wydającemu te akty ${ }^{22}$. Tytułem przykładu można wskazać, iż formę rozporządzenia ustawodawca przewidział dla rządowego programu pomocy społecznej mającego na celu ochronę poziomu życia osób, rodzin i grup społecznych oraz rozwój specjalistycznego wsparcia (art. 24 ust. 1 ups). Rację ma I. Sierpowska twierdząc, że „wybór takiego źródła prawa poprawia niewątpliwie efektywność programu, a warunki jego realizacji nabierają mocy powszechnie obowiązującej" ${ }^{23}$. Z kolei w ustawie o opiece nad dziećmi w wieku do lat 3 ustawodawca wskazał jedynie, że minister właściwy do spraw rodziny opracowuje resortowe oraz rządowe programy rozwoju instytucji opieki nad dziećmi w wieku do lat 3 oraz finansowo wspiera te programy (art. 62 ust. 1), nie rozstrzygając kwestii ich formy prawnej. Wobec powyższego należy zgodzić się z S. Grajewskim, że „mają one charakter aktu kierownictwa wewnętrznego i jako takie nie wymagają szczególnej formy wydania i ogłoszenia". Słusznie zaznaczył dalej autor, że z uwagi na grupę ich adresatów

(organy administracji rządowej, gminy oraz podmioty niepubliczne: osoby fizyczne, osoby prawne jednostki organizacyjne nieposiadające osobowości prawnej) oraz treść (tryb i kryteria dopuszczalności programu, w tym określone obowiązki dla podmiotów ubiegających się o udział w nim), należy przyjąć, że bardziej właściwe byłoby nadanie mu formy aktu powszechnie obowiązującego ${ }^{24}$.

Programy i strategie stanowione przez jednostki samorządu terytorialnego przybierają najczęściej formę uchwały rady gminy, powiatu czy sejmiku województwa. Wnikliwej analizie przedstawicieli doktryny zostały poddane zwłaszcza akty planowania stanowione na podstawie ustawy o pomocy społecznej. Jak trafnie dostrzegają R. Michalska-Badziak i K. Wlaźlak, sama forma uchwały nie przesądza jeszcze o zakresie obowiązywania strategii czy programu ${ }^{25}$. W rozważaniach zmierzających do rozstrzygnięcia, czy akty planowania stanowione przez jednostki samorządu terytorialnego $\mathrm{w}$ dziedzinie pomocy społecznej są aktami

${ }^{22}$ Szerzej zob. np. M. Grzybowski, Rada Ministrów i Administracja Rządowa, [w:] R. Hauser, Z. Niewiadomski, A. Wróbel (red.), System prawa administracyjnego, t. 2: Konstytucyjne podstawy funkcjonowania administracji publicznej, C.H. Beck, Warszawa 2012, s. 144; L. Garlicki, Polskie prawo konstytucyjne. Zarys wykładu, Wolters Kluwer SA, Warszawa 2014, s. 285.

${ }^{23}$ I. Sierpowska, Ustawa o pomocy spolecznej. Komentarz, (komentarz do art. 24), Wolters Kluwer SA, Warszawa 2009; LEX 2015, nr 7978.

${ }^{24}$ S. Grajewski, [w:] S. Grajewski, A. Jakubowski, Ustawa o opiece nad dziećmi w wieku do lat 3. Komentarz, LEX 2014, nr 8852.

${ }^{25}$ R. Michalska-Badziak, K. Wlaźlak, Akty prawne w dziedzinie pomocy społecznej stanowione przez organy samorzadu terytorialnego, [w:] M. Stahl, Z. Duniewska (red.), Legislacja administracyjna. Teoria, orzecznictwo, praktyka, Warszawa 2012, s. 478. 
powszechnie obowiązującymi, czy też mają charakter wewnętrzny istotne jest stanowisko wyrażone przez WSA w Białymstoku, który w wyroku z dnia 2 lutego 2006 r. (sygn. akt II SA/Bk 618/05, niepubl.) uznał, że jeśli treścią programu są przepisy mające charakter prognoz, analiz, planów i zasad polityki, jaką mają prowadzić organy wykonawcze, program taki nie jest aktem obowiązującym powszechnie. Mimo że strategie i programy przyjmowane przez jednostki samorządu terytorialnego są wiążące dla ich organów wykonawczych i niewątpliwie w sposób pośredni oddziałują na zachowanie podmiotów usytuowanych poza strukturą administracji, nie mogą bezpośrednio wpływać na ich uprawnienia i obowiązki ${ }^{26}$.

\section{KLASYFIKACJA I EGZEMPLIFIKACJA AKTÓW PLANOWANIA}

Akty planowania klasyfikować można z uwagi na szereg cech je wyróżniających.

Według kryterium nazwy nadanej przez prawodawcę można wyróżnić zwłaszcza programy, plany, strategie. W nauce prawa administracyjnego znane są różne określenia aktów planowania, wśród przejawów planistycznej aktywności administracji w zakresie ochrony rodziny i opieki nad nią decydujące znaczenie mają jednak strategie i programy. Pojęcia te występują w aktach prawnych, lecz nie posiadają swoich definicji legalnych. Przypisywane im znaczenia wynikają $\mathrm{w}$ znacznej mierze $\mathrm{z}$ dorobku nauk pozaprawnych ${ }^{27}$.

Biorąc pod uwagę kryterium twórcy aktu planowania - podmiotu tworzącego dany akt - można wyróżnić akty planowania tworzone przez administrację rządową (w tym centralną) oraz jednostki samorządu terytorialnego. Mogą to być akty rządowe, resortowe, wojewódzkie, powiatowe, gminne; tworzone przez administrację i przez podmioty administrujące; tworzone samodzielnie i tworzone we współpracy (np. zgodnie z art. 186 pkt 7 uwr wojewoda współdziała z ministrem właściwym do spraw rodziny przy opracowywaniu, realizacji i finansowaniu programów wspierania rodziny i systemu pieczy zastępczej).

Uwzględniając kryterium związania podmiotu tworzącego akt planowania, można wyróżnić akty obligatoryjne i fakultatywne. Jako przykład można podać unormowanie art. 176 pkt 1 uwr, z którego wynika, iż do zadań własnych gminy należy opracowanie i realizacja 3-letnich gminnych programów wspierania rodziny. Innym aktem planowania, którego ustanowienie ma charakter obligatoryjny, jest program na dofinansowanie zadań własnych gminy i powiatu z zakresu realizacji zadań wspierania rodziny oraz systemu pieczy zastępczej. Obowiązek

\footnotetext{
${ }^{26}$ R. Michalska-Badziak, K. Wlaźlak, op. cit., s. 478-479.

${ }^{27}$ Szerzej M. Górski, J. Kierzkowska, op. cit., s. 189-190.
} 
wprowadzenia tego programu został nałożony na ministra właściwego do spraw rodziny na podstawie art. 247 uwr. Wiele spośród aktów planowania ma charakter fakultatywny. Na podstawie art. 27 ust. 1 ustawy o Karcie dużej rodziny rada gminy, rada powiatu oraz sejmik województwa mogą uchwalić samorządowy program przyznający uprawnienia członkom rodzin wielodzietnych. Art. 187a ustawy o wspieraniu rodziny i systemie pieczy zastępczej stanowi, iż Rada Ministrów może przyjąć rządowy program wsparcia rodzin z dziećmi. Fakultatywny charakter mają także lokalne programy pomocy społecznej, których możliwość opracowania i skierowania do wdrożenia posiada rada gminy na podstawie 110 ust. 10 ups $^{28}$.

Kryterium podziału aktów planowania może stanowić też horyzont czasowy ich obowiązywania. Co do zasady akty planowania mają ściśle wytyczony okres obowiązywania. W nauce prawa administracyjnego wręcz podkreśla się, iż jest to cecha charakterystyczna tej formy aktywności administracji. Przykładowo gminne programy wspierania rodziny obejmują okres 3 lat. Program na dofinansowanie zadań własnych gminy i powiatu z zakresu realizacji zadań wspierania rodziny oraz systemu pieczy zastępczej jest przykładem programu jednorazowego: dofinansowanie miało obejmować okres 3 lat od dnia wejścia w życie przywołanego aktu prawnego. Z kolei Resortowy program rozwoju instytucji opieki nad dziećmi w wieku do lat 3 „MALUCH”, którego podstawę prawną stanowi art. 62 ust. 1 ustawy o opiece nad dzieckiem w wieku do lat 3 , realizowany jest w postaci jednorocznych edycji.

Część aktów planowania ma charakter samoistny, pozostałe są fragmentem innego planu, programu bądź strategii. Wskazać tutaj należy opracowywane przez samorząd województwa programy dotyczące wspierania rodziny i systemu pieczy zastępczej stanowiące - w myśl art. 183 pkt 2 uwr - integralną część strategii rozwoju województwa.

Wyróżnić można akty planowania bezpośrednio nakierowane na ochronę i opiekę rodziny (np. rządowy program mający na celu ochronę poziomu życia osób, rodzin i grup społecznych oraz rozwój specjalistycznego wsparcia, którego możliwość przyjęcia przewiduje art. 24 ust. 1 ups) oraz spełniające tę funkcję w sposób pośredni (jak np. Narodowy Program Profilaktyki i Rozwiązywania Problemów Alkoholowych).

${ }^{28}$ Wojewódzki Sąd Administracyjny w Lublinie w wyroku z dnia 13 grudnia 2011 r. sygn. akt sygn. III SAB/Lu 34/11 wskazał: stosownie do art. 17 ust. 2 pkt 4 u.p.s. - do kompetencji gminy należy również ,podejmowanie innych zadań z zakresu pomocy społecznej wynikających z rozeznanych potrzeb gminy, w tym tworzenie i realizacja programów osłonowych". Wykładnia gramatyczna art. 17 ust. 2 pkt 4 u.p.s. nie pozostawia zatem żadnych wątpliwości co do tego, że zadania wymienione w tym przepisie są nadobowiązkowe, bowiem tworzenie i realizacja programów osłonowych nie wynika z nakazu ustawodawcy, lecz ,z rozeznanych potrzeb gminy”. Opracowanie i kierowanie do wdrożenia lokalnych programów pomocy społecznej, o których mowa w art. 110 ust. 10 u.p.s., jest fakultatywne, a nie obligatoryjne. Wynika to z użycia zwrotu „Rada gminy, biorąc pod uwagę potrzeby, o których mowa w ust. 9". 
Biorąc pod uwagę kryterium podstawy prawnej, można wyróżnić akty planowania tworzone na podstawie konkretnej normy ustawowej (rządowe programy wspierania rodziny i systemu pieczy zastępczej, art. 187 ust. 1 pkt 5 uwr) i na podstawie normy ogólnej (art. 136 ust. 2 ustawy o finansach publicznych stanowi, iż programy wieloletnie są ustanawiane przez Radę Ministrów w celu realizacji strategii przyjętych przez Radę Ministrów, w tym w zakresie obronności i bezpieczeństwa państwa; Rada Ministrów, ustanawiając program, wskazuje jego wykonawcę. Na tej podstawie ustanowiony został uchwałą Rady Ministrów z dnia 10 grudnia 2013 r. wieloletni program wspierania finansowego gmin w zakresie dożywiania - „Pomoc państwa w zakresie dożywiania” - na lata 2014-2020).

Jak już zasygnalizowałam, można wyróżnić także akty planowania o charakterze normatywnym i takie, które nie mają charakteru normatywnego. Charakter prawny aktu planowania jest jednym z czynników decydujących o jego egzekwowalności. Stopień możliwości egzekwowania postanowień danego planu, programu czy strategii może stanowić kolejne kryterium ich delimitacji.

Przepisy ustawowe w bardzo różny sposób wyznaczają treść aktów planowania. Tytułem przykładu można wskazać programy osłonowe tworzone na podstawie przepisów ustawy o pomocy społecznej. O ile w przypadku gminnych programów osłonowych prawodawca przyjął, że ich tworzenie i realizacja ma wynikać $z$ rozeznanych potrzeb gminy, to już programy osłonowe tworzone przez ministra właściwego do spraw zabezpieczenia społecznego nie zostały poddane tego typu ograniczeniom. Zazwyczaj jednak treść aktów planowania wyznaczana jest w sposób bardziej ścisły. Przykładowo w ustawie o przeciwdziałaniu przemocy w rodzinie zapisano, że w celu tworzenia warunków skutecznego przeciwdziałania przemocy w rodzinie Rada Ministrów przyjmie Krajowy Program Przeciwdziałania Przemocy w Rodzinie, określający szczegółowe działania w zakresie: 1) zapewnienia ochrony i udzielania pomocy osobom dotkniętym przemocą w rodzinie; 2) oddziaływań korekcyjno-edukacyjnych wobec osób stosujących przemoc w rodzinie; 3) podnoszenia świadomości społecznej na temat przyczyn i skutków przemocy w rodzinie oraz promowania metod wychowawczych bez użycia przemocy; 4) upowszechniania informacji o możliwościach i formach udzielania pomocy zarówno osobom dotkniętym przemocą, jak i stosującym przemoc w rodzinie. Rządowe programy rozwoju instytucji opieki nad dziećmi w wieku do lat 3 określają tryb i kryteria wyboru podmiotów korzystających z nich, w szczególności uwzględniając: 1) jakość lub zakres oferowanych usług; 2) zapotrzebowanie na usługi świadczone przez te podmioty; 3) minimalny okres funkcjonowania instytucji lub miejsc opieki dofinansowanych z dotacji budżetu państwa (art. 62 ust. 1 i 2 ustawy o opiece nad dziećmi w wieku do lat 3). 


\section{INNE AKTY O CHARAKTERZE PLANISTYCZNYM}

Przywołane akty prawne nakazują tworzenie szeregu innych dokumentów, określanych mianem planów, których charakter zdecydowanie różni się jednak od wskazanych powyżej aktów planowania. Na przykład art. 185 ust. 2 uwr nakłada na kierownika regionalnego ośrodka polityki społecznej obowiązek przedstawiania zarządowi województwa corocznych planów działań interwencyjnego ośrodka preadopcyjnego, regionalnej placówki opiekuńczo-terapeutycznej oraz ośrodka adopcyjnego.

Jak słusznie wskazują M. Górski i J. Kierzkowska,

przepisy materialnego bądź ustrojowego prawa administracyjnego nakładają obowiązek przyjmowania tego rodzaju planów na wiele różnych organów, można ten obowiązek uznać za wręcz rutynowym. Plany takie, ich prawidłowość formalna i merytoryczna, oraz działania je realizujące mają oczywiście istotne znaczenie z punktu widzenia wykonywania zadań i osiągania celów stawianych przed aparatem administracji. Plany te powinny być przyjmowane i realizowane nawet wówczas, gdy przepisy w sposób wyraźny nie nakładają takiego obowiązku na dany organ (urząd). Obowiązek taki wywieść można bowiem z ogólnych zasad funkcjonowania administracji publicznej, w szczególności z obowiązku skutecznego wykonywania obciążających administrację publiczną zadań ${ }^{29}$.

Z ustawy o wspieraniu rodziny i systemie pieczy zastępczej wynika m.in. obowiązek przygotowywania planów pracy z rodziną i planów pomocy dziecku. Opracowanie i realizacja planu pracy z rodziną należy do zadań asystenta rodziny. Asystent rodziny w wykonywaniu tego zadania jest zobligowany współpracować z członkami rodziny i w konsultacji z pracownikiem socjalnym, który przeprowadzał w rodzinie wywiad środowiskowy. Plan pracy z rodziną obejmuje zakres realizowanych działań mających na celu przezwyciężenie trudnych sytuacji życiowych, a także zawiera terminy ich realizacji i przewidywane efekty. Gdy dziecko jest umieszczone w pieczy zastępczej, asystent rodzinny we współpracy z członkami rodziny i koordynatorem rodzinnej pieczy zastępczej opracowuje plan pracy z rodziną, który jest skoordynowany z planem pomocy dziecku.

Plan pomocy dziecku jest dokumentem przygotowywanym przez koordynatora rodzinnej pieczy zastępczej we współpracy z asystentem rodziny i odpowiednio rodziną zastępczą lub prowadzącym rodzinny dom dziecka. W przypadku, gdy dziecko umieszczone jest w placówce opiekuńczo-wychowawczej, plan pomocy dziecku sporządza i realizuje wychowawca we współpracy z asystentem rodziny. Organizator rodzinnej pieczy zastępczej wspiera dyrektora placówki opiekuńczo-wychowawczej typu rodzinnego w sporządzeniu planu pomocy dziecku.

${ }^{29}$ M. Górski, J. Kierzkowska, op. cit., s. 187. 


\section{PODSUMOWANIE}

Akty planowania stanowią istotną i różnorodną grupę wśród przejawów aktywności administracji. Jej liczność implikowana jest przez liczbę zadań o charakterze planistycznym nałożonych na organy administracji publicznej.

Zastanawiać może, czemu prawodawca dysponujący szerokim wachlarzem wydawałoby się bardziej skutecznych form działania administracji tak chętnie sięga po plany, programy czy strategie. Czy przyczyn takiego stanu rzeczy należy doszukiwać się w chęci uniknięcia proceduralnych trudności (o wiele prościej ustanowić program niż uregulować daną kwestię na drodze ustawowej) czy też w przejmowaniu wzorów prawodawstwa unijnego. Stanowienie planów i innych zbliżonych form jest wyrazem patrzenia perspektywicznego, powoduje też wzrost świadomości społeczeństwa oraz możliwość rozeznania potrzeb i urzeczywistniania oczekiwań. Być może jest to więc swoista droga dochodzenia do tzw. dobrej administracji.

\section{BIBLIOGRAFIA}

Dąbek Dorota. 2015. Prawo miejscowe. Warszawa: Wolters Kluwer SA.

Duniewska Zofia. 2009. Podstawowe pojęcia prawa administracyjnego. W Materialne prawo administracyjne. Pojęcia, instytucje, zasady w teorii i orzecznictwie. Red. Stahl Małgorzata. 90. Warszawa: Wolters Kluwer SA.

Duniewska Zofia, Górski Marek, Jaworska-Dębska Barbara, Olejniczak-Szałowska Ewa, Stahl Małgorzata. 2005. Plany, strategie, programy i inne zbliżone formy prawne działania administracji publicznej. W Podmioty administracji publicznej i prawne formy ich działania. Studia i materiaty z Konferencji Naukowej poświęconej Jubileuszowi 80-tych urodzin Profesora Eugeniusza Ochendowskiego. 143. Toruń: Towarzystwo Naukowe Organizacji i Kierownictwa „Dom Organizatora".

Garlicki Leszek. 2014. Polskie prawo konstytucyjne. Zarys wykładu. Warszawa: Wolters Kluwer SA.

Górski Marek, Kierzkowska Joanna. 2012. Strategie, plany i programy. W System prawa administracyjnego. T. 7. Prawo administracyjne materialne. Red. Hausner Roman, Niewiadomski Zygmunt, Wróbel Andrzej. 179-220. Warszawa: C.H. Beck.

Gajewski Sebastian, Jakubowski Aleksander. 2014. Ustawa o opiece nad dziećmi w wieku do lat 3. Komentarz. Warszawa: Wolters Kluwer SA.

Grzybowski Marian. 2012. Rada Ministrów i Administracja Rządowa. W System Prawa Administracyjnego. T. 2. Konstytucyjne podstawy funkcjonowania administracji publicznej. Red. Hausner Roman, Niewiadomski Zygmunt, Wróbel Andrzej. 144. Warszawa: C.H. Beck.

Jaśkowska Małgorzata. 2010. Uznanie administracyjne a inne formy władzy dyskrecjonalnej administracji publicznej. W System prawa administracyjnego. Instytucje prawa administracyjnego. Red. Hausner Roman, Niewiadomski Zygmunt, Wróbel Andrzej. 213-303. Warszawa: C.H. Beck.

Kotarbiński Tadeusz. 1960. „Walory dobrego planu”. Nauka Polska 1960 1: 48. 
Michalska-Badziak Ryszarda, Wlaźlak Katarzyna. 2012. Akty prawne w dziedzinie pomocy społecznej stanowione przez organy samorządu terytorialnego. W Legislacja Administracyjna. Teoria, orzecznictwo, praktyka. Red. Stahl Małgorzata, Duniewska Zofia. 478. Warszawa: Wolters Kluwer SA.

Niewiadomski Zygmunt. 2011. Samorząd terytorialny. W System prawa administracyjnego. T. 6. Podmioty administrujace. Red. Hausner Roman, Niewiadomski Zygmunt, Wróbel Andrzej. 129-161. Warszawa: C.H. Beck.

Sierpowska Iwona. 2009. Ustawa o pomocy społecznej. Komentarz, (komentarz do art. 24). LEX 2015, nr 7978. Warszawa: Wolters Kluwer SA.

Stahl Małgorzata. 2013. Szczególne prawne formy działania administracji. W System Prawa Administracyjnego. T. 6. Prawne formy działania administracji. Red. Hausner Roman, Niewiadomski Zygmunt, Wróbel Andrzej. 370. Warszawa: C.H. Beck.

Szlachetko Jakub. 2012. Uwagi na temat współpracy podmiotów spoza systemu administracji publicznej przy stanowieniu aktów planistycznych przez organy administracji zdecentralizowanej. W Partycypacja obywateli i podmiotów obywatelskich $w$ podejmowaniu rozstrzygnięć publicznych na poziomie lokalnym. Red. Stec Mirosław, Mączyński Marek. LEX nr 154449. Warszawa: Wolters Kluwer SA.

\title{
Anna Krygier
}

\section{PLANNING ACTIVITY OF THE PUBLIC ADMINISTRATION IN THE AREA OF FAMILY PROTECTION AND CARE}

\begin{abstract}
The study is aimed at presenting a group of instruments used in Polish administrative law to protect a family. The main focus is placed on showing a variety of plans, programmes, strategies and other similar forms of activity of public administration, which are issued by the state administration and self-government administration. Special attention is paid to a legal nature of plans and tasks connected with planning.
\end{abstract}

Keywords: family, care and protection, public administration, planning, public tasks. 